\title{
NATO's Current Policies on War Against Terrorism
}

\author{
Ph.D. Candidate Eljona Plaku
}

\author{
History Department \\ Mobile: 00355/0695311636, E-mail: eljonaplaku@ymail.com
}

\author{
Ph. D. Candidate Eliana Ibrahimi (Tafa)
}

History Department

Mobile: 00355/0692683279, E-mail: eliana22al@yahoo.it

Doi:10.5901/mjss.2013.v4n10p374

\begin{abstract}
Terrorism can be defined as the systematic use (or threat) of violence for achieving political and religious intentions or intentions pertaining to national liberation, directed to a symbolic target or to a group of victims, causing massive fear in the social group considered as opponent, whom is not necessarily related with the terrorist purpose. Generally, terroristic violence has as target ethnical groups, governments, political parties, corporations and the media. Beside the significant fact that terrorist organizations are smaller in number and restricted in source, compared to population and to the institutions are against off, today they must be taken more than seriously. In this context, it matters knowing terrorism as a concept and at the same time as a phenomenon of our present days. As a phenomenon, which threats constantly and increasingly the international security, it has evidently drawn the attention of international organisms for security preservation. In this issue an important place is reserved to the North Atlantic Organization, which soon after the '90s, when many thought of the end of it, saw itself confronting new challenges. In the context of these challenges, NATO had to reorganize its strategic post-Cold War concept.In this line, the discussion will offer a descriptive and analyzing point of view toward developments with a transforming character of the Alliance, in the context of new threats, where the widest attention will be dedicated to war on terrorism. The new environment of security is changing very fast asking for the transformation of the Alliance to be fast and fruitful too.
\end{abstract}

Keywords: NATO, extremism, terrorism, inter-border crime, cybernetic attacks, antiterrorist operations, intelligence services

\section{Introduction}

During the beginning of the $90 \mathrm{~s}$, terrorism was a common expression used once in a while among scholars of international relations, while today terrorism is continuously mentioned as the topic of the day in NATO's agenda. NATO has to find the balance between its missions in Europe and the treatment of worldwide threats, threats NATO is confronting nowadays are more real and often very unpredictable. Among these threats an important place belongs to the growing danger of terrorist attacks, which culminated with the events of September 11, 2001.

The basic rule of the North Atlantic Treaty is clearly expressed in the fifth Article of the Treaty. This rule would be taken in consideration immediately following the attacks of September 11, 2001, attacks that brought into NATO's attention its basic duty: the preservation of stability and security in the Euro-Atlantic area and further. After these events members of the Alliance in collaboration with their partners are co-ordinating their work and efforts for a similar situation not be repeated, as it will be treated further in the discussion.

\section{Terrorism - the new challenge of the Western World}

Terrorism can be defined as the systematic use (or threat) of violence for achieving political and religious intentions or intentions pertaining to national liberation, directed to a symbolic target or to a group of victims, causing massive fear in the social group considered as opponent, whom is not necessarily related with the terrorist purpose (Hyde, "International terrorism - conceptualization and terminology", The Institute of Democracy and Interaction for Security Issues-9, p 58). This is not an absolute definition of terrorism because among scholars circulate other ideas about this phenomenon that has a worrying and threatening widespread at the same time. Despite the criminal behavior of terrorists, this behavior is not considered the same in all places: in this context, the understanding of the criminal acts is depended on the political 
system, because there are states where a criminal act is considered as terrorism and at the same time exist states where this acts are seen as heroic and vice-versa (Krasniqi, International Terrorism, 2005, p 23). Despite of what is mentioned above we have two elements that define a criminal act as terrorism:

1. First element is related with the degree and the level of the organization of the doer.

2. Second element is related with the structure and the social reaction, respectively toward the act of crime (Krasniqi, international Terrorism, 2005, p 24).

Even though different scholars can mention other elements about the concept of terrorism, these remain secondhand when you notice the expanding tendency of this phenomenon in our century. His threat is serious not only on national but also international level. We have dozens of countries and hundred of cases where terrorism had harsh consequences. Incarnating the situation of anarchy in our present life - turning it more and more into a nightmare terrorism is related with the kidnapping of business people, killing of political leaders, setting bombs at the embassies or hijacking airplanes etc. (Alexander, "War on Terrorism" Tirana 2004, p 13). Terrorist acts are not something new for the human society, all contrary are used since the earlier times as a form of reaction, protest and profit. Examples of terrorism we can mention the attacks taken by the Jewish religious extremists (at the year 70 of the $1^{\text {st }}$ century), also known as 'the sikari zealots', against the Romans in the invaded Jerusalem and in the martyr missions of the 'hashashins' (killers) targeting crusaders in the Middle East $\left(11^{\text {th }}-13^{\text {th }}\right.$ century) (Alexander, "War on Terrorism", Tirana 2004, p 16). Since the period of the Roman Empire up to the events of September 11, 2001, this form of violence is being modified continuously becoming dangerous using every day more new options of technology, victimizing, or even threats. Above all terrorism is unpredictable and too dangerous. But its modification is only one side of the coin, as the other side is much more problematic because in almost all historic periods terrorism has been active it has resulted very attractive for the individuals involved in terrorist acts. Must be highlighted that this seduction of being part in a terrorist organization is closely related to the psychological aspect of humans. The recruiting of individuals (men, women, children) is resulting very successful, probably because of the dissatisfaction toward the system, the feeding of nationalist hatred, admiration of figures that after violent acts turn into heroes, but the most interesting part is the idea of self-sacrifice without fearing death as after the action what waits is heaven. This brain-wash that is being made to the new generation - mainly in the Islamic countries - is probably the main part of the chain, which if broken would considerably reduce the growing trend of terrorism. But this it is not something easy to do! Terrorism acts behind the scenes!

To understand the anonymity of terrorism is sufficient to see the alarming data related to the terrorist attacks. There were 7,294 reported terrorist incidents in 75 different countries in 2012, versus 12,122 in preceding year. These incidents claimed 11,450 lives, caused 21,218 injuries and included 813 abductions. The incidents decreased roughly $40 \%$ in the world compared to previous year (CEDAT, Annual Terrorism Report 2012, p 3). The most affected countries according to the number of incidents are as below:

1) Iraq, 2)Pakistan, 3)Afghanistan,4)India, 5)Yemen, 6)Somalia, 7)Turkey, 8)Columbia, 9)Thailand, 10)Syria etc.

Despite the decrease of numbers, the situation will continue to be a problematic one, also for the fact that in the area of terrorism we have the appearance of WMDs (weapons of mass destruction). Just like terrorists modify themselves without a stop their opponents too need to improve themselves and the methods of predicting, discovering and preventing terrorist acts!

\section{NATO, toward a new concept for facing terrorism.}

The North Atlantic Treaty Organization (NATO) was created on April 4, 1949, with the signing of the Treaty from ten of the founding European countries and two north-American: Belgium, Denmark, France, Great Britain, Iceland, Italy, Luxembourg, Nederland, Norway, and Portugal and Canada together with the United States of America. The main intention of the founding members was to come against the danger of Soviet Union expansion in Europe. With this agreement, all members were dedicated to the fair protection of freedom and security through their political and military means ("NATO summarized", Atlantic Committee of Albania, p 9). The end of the $20^{\text {th }}$ century the nature of NATO's challenges changed completely and significantly. Changes of the $90 \mathrm{~s}$ record a range of events important even to NATO, which for the first time offered help to the Soviet Union and to other European countries that were not members.

NATO's later policy would be mainly focused in issues of national security. We can mention here: Roman Declaration for Peace and Co-operation (1991), The Peace Partnership (1994), The Washington Summit where it was delineated the New Strategic Concept of NATO for the $21^{\text {st }}$ century (1999). An important stopover of the works of the Alliance would be the Summit of Prague (2002), where it was created Prague's Dedication on the Abilities in attempt to confront international terrorism as to make decisions related to the conversion of the military abilities of the Alliance 
("NATO summarized", Atlantic Committee of Albania, p 12). In this summit the member states created an Action Plan, which involved all partner states in exchanging intelligence information and the improvement of the readiness for a possible attack against the civil population with nuclear, chemical or biological weapons.

To come later to the reunion of high level in Istanbul (2004) where NATO's leaders increased anti-terrorist attempts of the Alliance, with the agreement to improve the exchange of information in the Secret Unit (created after the attacks of September 11) and to develop new protection with advanced technology against terrorist attacks. The Allies agreed to improve the interchange of information in the Secret Unit by revising the present secret structures of NATO and through the Secret Union for Terrorist Threats at the General Headquarters of NATO in Brussels (NATO Public Diplomacy Division "NATO after Istanbul", p 5). Beside this was created even a mechanism with partner states of the Committee of the Euro-Atlantic partnership and of the Mediterranean Dialogue in order to facilitate the interchange of intelligent information about terrorist threats.

Riga's Meeting held on November 28-29, 2006 was an important event for NATO. State and government leaders from the $26^{\text {th }}$ members of NATO were gathered for the $8^{\text {th }}$ time since the end of the Cold War, in the capital of one of the new members of NATO. In the meeting were rewritten the directions of NATO's policies but importance in this study represents the issue of terrorism, which in Riga took more special attention. Member states approved in unanimity that they punish terrorism, whatever being its reasons and appearances and that they will fight all together as long as needed in consistency with the international law and the UNO principles. It was strongly said that the allies would support the dialogue and co-operations with their partners and other international organizations to fight terrorism and highlighted the decisiveness to protect the population, territories, infrastructure and the military forces toward the consequences of terrorist attacks.

In this meeting the 'Directive' defined the kinds of operations that the Alliance must be in condition to take over, and the kinds of abilities needed: NATO's military forces must be leveled, elastic and versatile, and able to do a range of missions, from those with the lowest intensity to those with the highest. The 'Directive' underlines the fact that is much probable that NATO should do a great number of war actions even up to the smallest levels (NATO Public Diplomacy Division "NATO after Riga, $p$ 2). The allies agreed to create a New Force of Response of NATO technologically advanced, able to quickly dislocate where needed, to operate as an accelerant and in order to stimulate improvements in the military abilities of the Alliance and their constant transformation. They also supported a scheme for a new military command structure with few people and more efficient (NATO in the $21^{\text {st }}$ century, www.nato.int, $p$ 21). This structure enumerates 25,000 troops, whom can start regrouping five days after the announcement and to preserve fighting action abilities for 30 days or even longer if supplied time after time. The closing proceedings of the Riga's Summit created the justified submission that the Alliance was being adapted to the security environment of the $21^{\text {st }}$ century through its operations, its transformed abilities of protection and deeper commitment to countries inside and outside the EuroAtlantic area, and through continuous reforms. Beside these transformations the Alliance has undergone, there are skeptics whom believe that the Alliance in her inner structure has some conflicts among member allies. This cannot be denied, if we take in consideration the fact that the main part is held by the United States while the European allies do not come closer to its capacities. What is needed for a quick reaction can be defined in four basic elements:

1. Big transportation airplanes to dislocate troops in distant battle fields.

2. Bombs and rockets that can be directed precisely hitting enemy targets with a high scale of certainty.

3. A large number of crews for special operations who can operate during the night using particular seeing equipments.

4. A safe and codified interconnection system, in a way that the land and areal units to be unified in a higher technological war while the enemy not being able to hear (Friedman, World in the Time of Terrorism, 2003, $p$ 120)

None of the member states (except the USA) does not fulfills these elements, and for this in Prague was further emphasized that: Transformation needs money, so each state must respond to the basic rule to pay in at the common cashbox 2\% of the annual GDP. Not too late, on November 22, 2010 the Alliance delineated the New Strategic Concept, in which it was dedicated a wide area to war on terrorism. In this summit was reconfirmed that the Alliance keeps being the most powerful political and military organization in the world. NATO's potential is not only military potential. The true power of NATO comes from the combination of the American military power with the economic power of the European countries which gives to the Alliance a universal political character, also a primary role in international relations. The new formula of NATO is expected to be "Active Commitment - Modern Protection". As far as, is concerned to this new strategic concept entitled "Active Commitment - Modern Protection", can be said that it contains new elements in correspondence with actual challenges of security, and new characteristics of the old concepts of security. The most 
special aspects of the New Concept include: the determination of the dangers and challenges of the Alliance, where are treated the widespread of weapons of mass destruction, extremism, terrorism and inter-border crime, cybernetic attacks and dangers originating from the technological development; the agreement of a consensus to develop the rocket protection and the commitment to have a nuclear power, also the presence of the American nuclear capacity in Europe up to the moment of total reduction of nuclear weapons: the creation of common capacities of the allies to confront new dangers: the improvement and creation of the new capacities to prevent and manage crises, also the after-conflict stabilization and reconstruction co-operating with other international and regional actors: strengthen and development of partnerships, also the execution of the 'open doors' politics for new members of the Alliance; the deep reformation and transformation of the Alliance from the perspective of civil and military structures in order to make it more elastic and efficient in accordance with the demands of time, changes that will belong shorten to the military structures dislocated in Europe ("Strategic Concept For the Defense and Security of the Members of the North Atlantic Treaty Organization', November 2010, www.nato.int). As was highlighted by the secretary of NATO, Rasmussen; 'The danger of the terrorist attacks and many other dangers comprise an international problem. As international problems they require multinational solutions. NATO is the highest multilateral organism for security, which undermines that it can and should give a real contribute. And we are being constructed to do exactly this.'("NATO, the Strategic Concept and the Way Forward", Keynote address by NATO Secretary General Anders Fogh Rasmussen to the participants of the Lisbon 2010 Young Atlanticist Summit, www.nato.int)

This policy was strengthen even more at the Summit of Chicago May 20, 2012 and is expected to the after summits, maybe during this summer to be emphasized once more the concrete interests of the Alliance, exactly in the course of war on terrorism. Paraphrasing the Summit of Chicago: Terrorism in all its forms and manifestation can never be tolerated or justified. We deplore all loss of life from act of terrorism and extendour sympathies to the victim. We reaffirm our commitment to fight terrorism with unwavering resolve in accordance with international law and the principles of the UN Charter. Today we have endorsed NATO's Policy Guidelines on Counter - Terrorism and task the council to prepare an Action Plan to further enhance NATO's ability to prevent, deter, and respond to terrorism by identifying initiatives to enhance our threat awareness, capabilities, and engagement (Chicago Summit Declaration, www.nato.int) Nowadays world has become very insecure. Terrorism has knows no limits, nations, states or religion, it just exists and has no intention for peace. The Alliance is determined to fight with all possible means.

\section{The politics of confronting terrorism}

Nowadays the importance of terrorism does not stand at the number of victims - in many cases wars or conflicts cause more victims, without bringing any reaction - but at the fact that its beginning in world scale makes possible to enter into another epoch of war and hostility. Global terrorism has nothing to do with the traditional partisan. Opposing the partisan, a terrorist does not want to take over the power or to physically control a territory as a logistic base or a recruitment zone. He does an asymmetric war, where more importance has the computer and telephone rather than weapons and ammunition. By usually hitting military people and civil, he intends the destruction of the enemies positions, without following at all 'resistance without a leader', so without having a vertical control and a centralized command, without following in this case the distinctions of a traditional war, a classic war. Their front is never reachable: in every place or nowhere. Their action has no territorial residence, neither clear geographical lines. Their realm is much more space than earth. But above all the greatest importance is psychological. To cause fear, anxiety and doubt, to hit imagination for having emotional effect, so terrorism has as an intention to offend in the psychological aspect, in order to outdistance its victims (De Benoist, Alain, "Terrorism Strategies in the 215t century, March 27, 2010). The change in terrorism's nature requires for the Alliance to contribute through troops and agencies to improve itself in order for the confronting with almost invisible enemy to result effective. In the immediate aftermath of the attacks in the United States and for the first time in its history, the Alliance invoked Article 5 of the Washington Treaty. This is the collective defense clause, which states that unarmed attack against one or more of the Allies shall be considered an attack against them all. This led to the launch of a naval counterterrorist surveillance operation in the Mediterranean, Operation Active Endeavour. The Allies also agreed a package of measures in support of the United States, including the deployment of NATO Airborne Early Warning and Control Aircraft (AWACS) to the US from mid-October 2001 to mid-May 2002 to protect the US homeland and free up US assets to be deployed for its campaign in Afghanistan ("NATO, the Strategic Concept and the way forward", Keynote address by NATO Secretary General Anders Fogh Rasmussen to the participants of the Lisbon 2010 Young Atlanticist Summit, www.nato.int)

As can be seen at the map, all around the world are dislocated a range of operations which operate efficiently for 
certain intentions, but all are related through terrorism as the most active enemy, which must be fought powerfully to eliminate any kind of emersion of unpredictable violence.

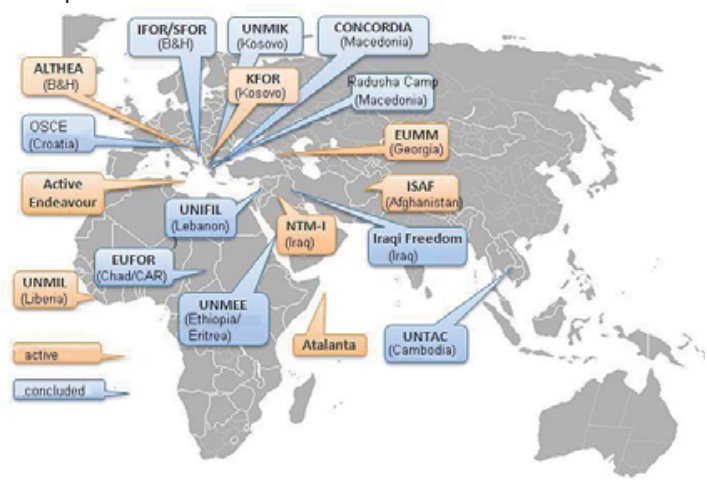

NATO's mission map, all over the world (www.nato.int)

NATO's contribution in the war on terrorism is present in many areas and many ways. decisions.

First of all, NATO is a permanent consultant committee, in the state to transform discussions into collective

Secondly, NATO is supported from military abilities and forces in concordance with Alliance's dispositions.

Thirdly, NATO is part of a wide system of partnership where are included other states and international organizations (NATO's Manual, NATO 2006)

In the frame of these roles the Alliance takes over to play in an international level, its work today is reflected in a range of missions all around the world (turning down the concept of geographic limitation) in supporting peace, development and collaboration.

As a response to these initiatives NATO has mobilized force as part of a wide system of partnership, involving other countries and international organizations as well. In this course, NATO leads a large number of operations and supports many initiatives to fight terrorism as it is presented below:

NATO's operations.

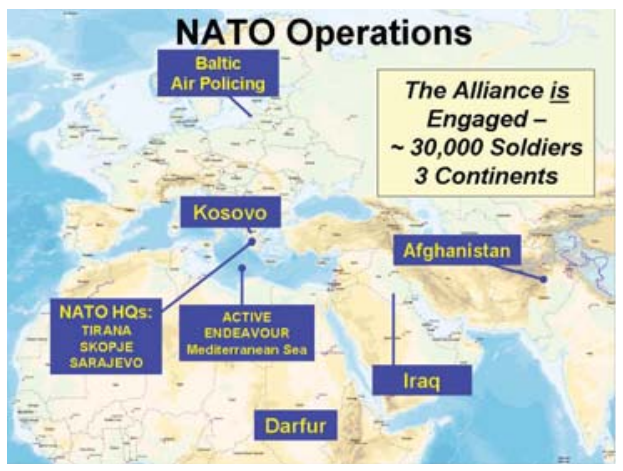

Operation Active Endeavour (OAE) is a maritime surveillance operation led by NATO's naval forces to detect, deter and protect against terrorist activity in the Mediterranean through monitoring, patrolling, escorting and compliant boarding. Initially limited to the Eastern Mediterranean, OAE was extended to the entire Mediterranean from March 2004. Managing the consequences of terrorist attacks. Consequence management involves reactive measures to mitigate the destructive effects of terrorist attacks, incidents and natural disasters. Improved intelligence-sharing. Since 11 September 2001, NATO has thought to increase consultations on terrorism and terrorism-related issues among its members, as well as with non-member countries. Information-sharing and, more specifically, intelligence-sharing are key aspects of this exchange.

The Partnership Action Plan against Terrorism (PAP-T.) The PAP-T was adopted at the Prague Summit in 
November 2002 drawing on the spirit of 12 September 2001, when the Euro-Atlantic Partnership Council (EAPC) condemned the attacks on New York and Washington D.C. the previous day and offered the support of all 46 EAPC members to the United States.

The Defense against Terrorism Program of Work. The Defense against Terrorism (DAT) Program of Work was developed by the Conference of National Armaments Directors (CNAD) in May 2004. It was later approved as part of an enhanced set of measures to strengthen the Alliance's fight against terrorism at the Istanbul Summit in June 2004. NATO'S DAT POW uses new or adapted technologies or methods to detect, disrupt and defeat asymmetric threats under three capability umbrellas:

1. Incident Management.

2. Force Protection/Survivability

3. Network Engagement (Countering terrorism, www.nato.int)

\section{Concluding remarks}

- Today NATO's war frame has completely changed. Old methods of respond are no longer resultant, as the next step is difficult to be predicted. For that, today are being exploited at the maximum diplomatic efforts, financial forms, intelligent services, highlighted aspects of the psychological war etc.

- NATO's efforts for reacting toward new threats will start with the Peace Declaration of Rome (1991) and will come up to our present days, strengthen summit after summit.

- In Riga the member states (26 at that time) declared that they decisively punish terrorism. Now fulfilled in ideas, the Alliance had to execute these ideas. In order for this to be done the 'Directive' assigned the kinds of operations the Alliance had to commit in its war on terrorism.

- However, what was about to characterize NATO in the present days and the decade we are living, was made clear in Summit of Lisbon and strengthen at the Summit of Chicago. These two summits were characterized by a collaboration that reconfirmed the commitment of member states and other partners of the Alliance in the area of international security. The new formula of NATO is expected to be "Active Commitment - Modern Protection".

- NATO has established a range of programs, for being a help to prevent terrorism (or manage its consequences). We can mention: The Action Plan against Terrorism, Science for Peace and Security (SPS), and a range of training courses and conferences among member states and partners that support anti-terrorist targets.

- As a support operate even missions on field, which give their direct or indirect contribution. A first hand importance is given to, the Operation Active Endeavour (OAE), managing the consequences of terrorist attacks, the Partnership Action Plan against Terrorism (PAP-T.), The Defense Against Terrorism Program of Work etc.

- Day after day, NATO is becoming an organization with a global character.

\section{References}

Alexander, Yonah, "War on terrorism", Tirana 2004.

CEDAT, Annual Terrorism Report 2012

Chicago Summit Declaration, www.nato.int

De Benoist, Alain, "Terrorism Strategies in the 21st century, March 27, 2010

Friedman, Thomas, "World in the Time of Terrorism", 2003

Hide, Enri, "International terrorism - conceptualization and terminology", The Institute of Democracy and Interaction for Security Issues-9.

Krasniqi, Kolë, "International Terrorism", Uegen, Tirana 2005.

NATO in the 21st century, www.nato.int

NATO's Manual, NATO 2006

NATO Public Diplomacy Division "NATO after Istanbul", NATO 2004

NATO Public Diplomacy Division "NATO after Riga", NATO 2006

"NATO summarized", Atlantic Committee of Albania, Tirana 2006

"NATO, the Strategic Concept and the Way Forward", Keynote address by NATO Secretary General Anders Fogh Rasmussen to the participants of the Lisbon 2010 Young Atlanticist Summit, www.nato.int

'Strategic Concept For the Defense and Security of the Members of the North Atlantic Treaty Organization', November 2010, www.nato.int. 